\title{
Incurably Religious? \\ Consensus Gentium and the Cultural Universality of Religion ${ }^{*}$
}

Jakob De Roover

Are there human societies and peoples without religion? For centuries, this question captivated some of the greatest minds of Europe. The potential existence of "tribes" and "civilizations" without religion caused anxiety in some and elation in others. Going by the debates from the early sixteenth to the late nineteenth century, this was one of the most significant challenges that the discovery of non-western cultures posed to the European intelligentsia. Whenever some traveller claimed that he had found "a people without religion" in Africa, Asia or the Americas, others would deny that this could be the case.

At the turn of the twentieth century, however, this concern largely vanished from the radar of western scholarship. Illustratively, authors now dismissed the question of "the fundamental universality and permanence of religions" as follows: "This great fact is no longer disputed by any one, it is one of those matters classified as 'definitely settled'" (Le Roy 1922:286-7). Or they announced that they had no intention of discussing this point, "because, as every anthropologist knows, it has now gone to the limbo of dead controversies" (Jevons 1896:7). Indeed, throughout the twentieth century, textbooks reproduced the claim that all known cultures or societies have some kind of religion. ${ }^{1}$ It remains alive today. A recent introduction to the anthropology of religion notes that in the past "claims were often made that religion was lacking in various societies." Today, however, "neither anthropologists nor, probably, any other scholars would accept claims...about the absence of religion in various societies. Anthropologists are now confident that religion is present in all human societies, even though some or many traditionally lack a word for religion in their own language and therefore do not separate 'religion' from other realms of culture" (Winzeler 2008:3).

Given that the universal presence of religion in all societies was a hotly debated question for centuries, we need to examine what issues were at stake before it was relegated to the limbo of dead controversies. Why was this question so important? How did European thinkers determine whether or not some people had religion? And what allowed

\footnotetext{
${ }^{*}$ The author would like to thank Philippe Bornet and the anonymous reviewer for Numen for valuable comments on earlier drafts of this essay.

${ }^{1}$ For some typical statements, see Nottingham 1954:1; Hoult 1958:3; Saliba 1976:22; Morris 1987:1; Llobera 2003:73.
} 
them to close this debate at the turn of the twentieth century? Identifying these issues is of particular importance today, because the debate concerning the cultural universality of religion has been reopened. On one hand, a small group of scholars is once again arguing that there are cultures without religion (Balagangadhara 1994, Dubuisson 2003, Staal 1989). On the other hand, another group of authors claims to have offered the ultimate evidence for the belief that all human cultures have religion: namely, an evolutionary-biological explanation of religion, which locates its origin in the biological evolution of the human species (e.g. Atran 2002, Boyer 2001, Dennett 2006, Rosano 2010, Wilson 2002).

This essay will first identify the central issues in the debates about the universality of religion preceding the consensus of the early twentieth century. It will show that these were problems of a particular framework, namely, generic Christian theology. European descriptions of non-western cultures counted as evidence for or against theoretical claims made within this theological framework. The terms and criteria used to assess the presence of religion in these cultures were embedded in the same framework. Consequently, this background framework also structured the basic descriptions of these cultures in terms of "religion." Next, the essay will explain how the debate on the existence of peoples without religion came to an end.

We will then examine the new challenge to the cultural universality of religion by turning to the work of S. N. Balagangadhara. He disputes the factual status of descriptions of the "religions" attributed to the peoples of Asia and suggests that the religions in question do not exist. This challenge, we argue, has not been appreciated by the recent batch of evolutionary-biological explanations of religion. Their authors not only presuppose that all human societies have had religion, but also accept earlier descriptions of such presumed "religions" as theory-neutral facts in need of explanation, even though these descriptions are structured by a theological framework. Finally, the essay concludes by arguing that the contemporary study of religion has a unique opportunity to settle the debate on the cultural universality of religion.

\section{The Consent of Nations}

In the last century before the Common Era, the great Roman orator Cicero wrote that there is an irrefutable argument for us to believe in the existence of the gods: namely, that "there never was any nation so barbarous, nor any people in the world so savage, as to be without some notion of gods" (Tusculan Disputations (I, XIII, 30)). Known as the argument consensus 
gentium, Cicero's sentence would be reproduced again and again in early modern Europe. ${ }^{2}$ However, the argument first underwent a fundamental transformation: a few centuries after Cicero, his Christian counterpart, the church father Lactantius, invoked "the testimony of communities and tribes" in his Divine Institutes (303-311 CE) to insist on the universality of the awareness that the Creator's divine providence governs the world. There is no one so uncivilized, he insisted, that when he contemplates the universe, he could ignore that it was regulated by some greater intelligence (2.1:11).

Transformed into a doctrine about the God of the Bible, the argument consensus gentium became of supreme import to the early Christian apologetics. Christians were often challenged as to the novelty of their religion, contrasted to the antiquity of Roman religio. In reply, apologists argued that Christianity was the most ancient religion of all: the original religion that God had bestowed on humanity at the time of creation, which had everywhere been corrupted, until it was restored through His revelation in Christ. In the second century $A D$, Justin Martyr wrote in his Hortatory Address to the Greeks (38:289) that Jesus Christ "restored to us the knowledge of the religion of our ancient forefathers, which the men who lived after them abandoned through the bewitching counsel of the envious devil, and turned to the worship of those who were no gods." In his Church History (1.4:88), Eusebius affirmed that "it is clearly necessary to consider that religion, which has lately been preached to all nations through the teaching of Christ, the first and most ancient of all religions..." Augustine put it even more clearly in his Retractationes (i.13), where he wrote that "the truth itself, which is now named the Christian religion, existed and was not missing among the ancients from the beginning of the human race, until Christ came 'in the flesh' from whom the true religion, which already existed, began to be called Christian" (Eller 1949:176). In between these two manifestations of true religion, humankind had wandered into false religion but retained traces of the original gift of God.

Importantly, this account both predicted and required the presence of religion among all human groups. As the Creator had given awareness of his existence to humanity, it appeared to have become theologically impossible that people without religion could exist. From the church fathers to the Renaissance, the belief in the universality of religion rested on Christian theology and its references to an imaginary consensus gentium. Much of the philological work of Renaissance humanists like Marsilio Ficino and Pico della Mirandola was fuelled by the search for a prisca theologia, a pristine theology or Urreligion that had supposedly provided the basic structure for all later religious systems (Idel 2002, Nelson

\footnotetext{
${ }^{2}$ For a general discussion of the argument consensus gentium, see O'Briant (1985).
} 
2010:11, Walker 1972). In his De Christiana Religione (1474), the neo-Platonist Ficino proposed "that religio, despite appearances, was at all times and in all places the same thing - namely, a universal property of humanity, a distinguishing characteristic, and the one thing which made humanity human." "The worship of god," he said, "is as natural to men, as is neighing to horses or barking to dogs" (Harrison 1990:13). Religion was not only the distinguishing feature of humanity, but there was a pure and ancient theological substratum common to all its forms.

The first dissenting notes that challenged the consensus gentium came from the reports of the early voyages of exploration. Both Christopher Columbus (1968:196) and Amerigo Vespucci (Wallisch 2002:20-21) made ambiguous observations about the absence of worship and idolatry among the inhabitants of the new world. Yet, the momentous changes during this period did not inspire any inquiry into the truth of the consensus. To the Protestant Reformers, the universal awareness of the biblical God became even more significant than before. For Huldrych Zwingli, this was the consequence of God's calling the sinner Adam back to Himself. The thirst after God was a universal experience found everywhere and native to us, which arose from humanity's creation in the image and likeness of its Creator (Preus 1977:195-6). John Calvin derived the "fact" that one could find no city or household without religion from the sensus divinitatis or sense of divinity imprinted by God on the human soul (Dowey 1952:50-56). "The knowledge of God has been naturally implanted in the minds of men," stated the title of a chapter in his Institutes of the Christian Religion (1536-1559):

\footnotetext{
If ignorance of God is to be looked for anywhere, surely one is most likely to find an example of it among the more backward folk and those more remote from civilization. Yet there is, as the eminent pagan says, no nation so barbarous, no people so savage, that they have not a deep-seated conviction that there is a God. And they who in other aspects of life seem least to differ from brutes still continue to retain some seed of religion. So deeply does the common conception occupy the minds of all, so tenaciously does it inhere in the hearts of all! Therefore, since from the beginning of the world there has been no region, no city, in short, no household, that could do without religion, there lies in this a tacit confession of a sense of deity inscribed in the hearts of all (1.3.1:44).
}

Here, we do not encounter any empirical inquiry into the universal existence of religion but a theological premise about the same. Dissent from this premise could only be inspired by lack of reason, Calvin added (1.3.3:45). Even heathen idolatry confirmed that "God has sown a seed of religion in all men" (1.4.1:47). His only "evidence" consisted of a modified citation from Cicero, where "God" had replaced "gods." 


\section{Universal Consent in the Seventeenth Century}

In the seventeenth century, as European travellers began to explore alien cultures in different parts of the world, the question of the presence or absence of religion in such cultures would become a central concern. Even where they went beyond Christian orthodoxies, however, these investigations occurred within a particular conceptual framework and were driven by central problems haunting European Christianity.

One of these problems was the fragmentation of Christendom into a series of conflicting confessions. This issue propelled the work of "the father of deism," Lord Herbert of Cherbury. If only one could identify the common notions shared by all of humanity, he argued in his De Veritate (1624), they would provide the foundation for a general harmony among human beings. Lord Herbert set out to disclose these notions, taking universal consent as "in the last resort the sole test of truth." Strikingly, he never questioned that religion was among these common notions sustained by universal consent, but simply stated that it was (1937:118-21). His task was not to find out whether religion is universal, but rather what is universal in religion.

How did Herbert know in advance that religion is a common notion of humanity? And how could he take universal consent to be the ultimate criterion of truth? As we know today, consensus gentium is a fallacy; in itself, the fact that all humans believe something can never establish the truth of that belief. These issues are resolved, once we realise that Herbert was searching for the original principles imprinted by the biblical God upon the human spirit:

\footnotetext{
It follows from these considerations that the Dogmas which recognise a sovereign Deity, enjoin us to worship Him, command us to live a holy life, lead us to repent our sins, and warn us of future recompense or punishment, proceed from God and are inscribed within us in the form of Common Notions (1937:302).
}

Proceeding from God, these original dogmas could not but be true. Inscribed within all human beings, they could not but be universal.

Were there peoples without religion? When this question was addressed, it was not as an empirical issue about alien cultures, but as a theological problem with equally theological solutions attached to it. Seventeenth-century Protestants and early deists assumed that all human beings had an intrinsic religiosity or "natural religion" - a simple belief in the Sovereign Creator of the universe, taught by "the light of nature." In a commonplace of this literature, religion rather than reason came to be seen as the 
distinctive property of humankind. Some brutes also show signs of a minimal reason, it was said, but only humanity had religion and the capacity for worshipping its Creator (Bennet 1732:653-4; Hale 1684:1; Wilkins 1678:288-9). Rather than rationality, "religion and faith" were "the unique and ultimate differences of man" (Herbert 1937:257). This claim buttressed early studies of the world's "religions," such as Alexander Ross' popular work Pansebeia, or, A View of All Religions in the World (1655). In his preface, Ross noted that atheists could not avoid shame and confusion, when they read his book, "in which they shall see, that no Nation hath been so wretched as to deny a Deity, and to reject all Religion; which Religion is a property no lesse essential to man, and by which he is discriminated from the Beasts, than rationality it selfe."

The same view was central to a second problem of seventeenth-century Christendom: the battle against atheism. The argument from universal consent had become a major proof for the existence of God. "Atheists" were said to deny this common sense that all nations had of Him. A series of authors in seventeenth-century France and England set out to prove them wrong. ${ }^{3}$ In his Antidote against Atheism, the Cambridge Platonist Henry More stated the following with certainty:

Now for Adoration or Religious Worship it is as universall as mankind, there being no Nation under the Cope of heaven that does not do divine worship to something or other, and in it to God as they conceive; wherefore according to the ordinary naturall light that is in all men, there is a God.

Some thinkers objected that heathens did not worship God, but instead bowed down to wood and stone. According to More, this also illustrated the deeply rooted "property of Religion in Man, that cannot be lost." It showed "that these poore barbarous Souls had once the true knowledge of God, and of his worship, and by some hidden providence may be recover'd into it again." The implantation of the idea of God in the soul had made it an "innate truth," confirmed by "the light of Nature that is universally received of men." No other faculty existed that could produce evidence to the contrary: "And such is the universall acknowledgment that there is a God" (More 1653:31-4).

From the late sixteenth century, a doubtful light had been cast on such conclusions, as new reports about the population of the New World reached Europe. These suggested the unthinkable: several American Indian tribes did not appear to have any religion. Similar claims surfaced about some African and Asian peoples encountered by European travellers (Chidester 1996:11-6; Kors 1990:142-50). They did not seem to know of any "Supreme

\footnotetext{
${ }^{3}$ See Allestree 1673:128; Baxter 1672:33-4; Care 1683; Cudworth 1678; Hale 1684:1; Kors 1990:17-43; Ross 1655.
} 
Being." There were nations so barbarous and peoples so savage, these reports emphasized, as to lack all religion. Fortunately, these groups could be brushed away as savages, whose humanity was suspect. But the problem of atheism threatened to turn acute, when French missionaries were said to have found a society of atheists in an ancient civilization. It concerned China and the "Confucianism" of its educated elite. Did this doctrine know of "God" or was it atheistic? For decades, different monastic orders and the philosophes disputed the issue. Eventually, the polemics required the interference of the Sorbonne and the Papal See, which decided in favour of the view that the Confucians were atheists (Kors 1990).

Inadvertently, this falsified the consensus gentium argument, since a civilized elite had now joined the savages as people without religion. The Jesuit father Louis Le Comte raised a crucial question: would it not be dangerous to religion, he said, to say "that the ancient Chinese, like those of the present, were atheists?" The "Libertines" would draw great advantage from this confession that an ancient, enlightened and flourishing empire had never acknowledged the Divinity: "What would become thus of the arguments that the holy fathers, in proving the existence of God, drew from the consent of all peoples, in whom they claimed that nature had so deeply imprinted the idea of Him, that nothing could erase it?" (cited in Kors 1990:171-2).

Another Jesuit, Father Joseph Lafitau, set out to save the consensus. In the early eighteenth century, he had spent six years as a missionary among the Iroquois. In 1724, he published his massive Moeurs des sauvages Amériquains comparée aux moeurs des premiers temps, one of the first works of comparative ethnology (Pagden 1987:198-210). Its purpose, Lafitau stated, was to establish the truth of the unanimous consent of nations in the matter of religion. With great distress, he had noted that travel narratives depicted the primitives "as people without any sentiment of religion, knowledge of a divinity or object to which they rendered any cult":

\footnotetext{
Now, in this way, what argument is not furnished to atheists? One of the strongest proofs against them of the necessity and existence of a religion is the unanimous consent of all peoples in recognizing a Supreme Being and honouring him in some way, a unanimity which shows that people feel his superiority and the need of turning to him.
}

If one could demonstrate the existence people without religion, one gave the atheist evidence for his claim that religion was but the artifice of human legislators and powerhungry priests. Therefore, it was necessary to destroy the false idea that the Indians did not 
have religion: "It is then a question only of proving this unanimity of opinion among all nations, showing that, indeed, there is none so barbarous as to have no religion or sanctioned customs" (Lafitau 1974:28-9).

Lafitau took the argument a step further. Not only do all these people whom we call barbarous have religion, he said, but it was also very similar to the religions of antiquity. Moreover, the latter were similar to the teachings of true faith:

In this same doctrine we see a religion, pure and holy in itself and in its origin, a religion emanating from God who gave it to our first fathers. There can be, in truth, only one religion and it...must have begun with them and existed as long as they. This is what faith teaches and religion dictates to us.

Therefore, human societies could not have lived without the strong bond of religion. On the contrary, the original divine religion was "passed from generation to generation as a kind of heritage common to all and thus spread everywhere" (30-35). Theological certainty, then, left no doubt whatsoever that religion was indeed universal: "Men need a religion." The issue had been settled; the consensus saved.

\section{Transforming Theology into Anthropology}

All these arguments derived from an explicit theological consensus that awareness of the biblical God and the desire to worship Him had been ingrained in humanity. This theological framework allowed these authors to perceive and conceptualize the traditional practices of all peoples as expressions of "religion." Within this framework, even practices like "bowing down to wood and stone" reflected the deeply-rooted human property of religion. However, the discovery of peoples without religion was not just a challenge to this explicit theological claim. Over centuries, the dominance of Christianity in Europe had generated an implicit anthropology or understanding of human beings. If nations without religion existed, then this entire anthropology would require revision. This was not a question of rejecting some isolated claim like "no people is so savage as to lack religion." It would involve re-examining an entire web of beliefs about humanity, from the most basic descriptions of the "religions" of Asia and Africa to the most sophisticated speculations about human nature.

For a moment, it seemed as though the early Enlightenment would go ahead with this task and reject the belief in the universality of religion. John Locke disputed the innateness of the idea of God and pointed out the following in the fourth edition of his Essay Concerning Human Understanding (1700:29): "Besides the Atheists, taken notice of amongst the Ancients, and left branded upon the Records of History, hath not Navigation discovered, 
in these latter Ages, whole Nations...amongst whom there was to be found no Notion of a God, no Religion." Such rejections of the innateness of the notion of God gave rise to the argument among French rationalist theologians that the collective reasoning of humanity had nevertheless produced the consensus that the Supreme Being exists. In reply, Pierre Bayle argued that the universal acknowledgement of some claim could never count as proof for its truth. Besides, he added, both ancient philosophy and the atheistic Chinese civilization demonstrated that there was no such unanimous consent (Israel 2006:71-85).

In the long run, the effects of this denial proved negligible: throughout the eighteenth century, authors reinforced the earlier consensus. On one hand, travel reports about alien cultures continued to conceptualize the practices of peoples in Asia, Africa and the Americas as expressions of (false) religion. That is to say, they assumed as true that these people had religion. As before, the resulting descriptions depended on the theological account of religion as a universal drive to worship the divine. Enlightenment scholars were less harsh towards "heathen religion" than missionaries. Like the latter, however, they rarely raised the question as to whether all these cultures really had religion.

On the other hand, there remained travelogues that noted the absence of religion among certain "savages." Confronted by these, other authors devised a set of strategies to save the consensus from refutation. The first strategy denied humanity to the peoples without religion. One author put it as follows: "By whatsoever steps any should advance in the denial of a Deity; they should proceed by the same, to the abandoning of their own humanity; and by saying there is no God, they should proclaim themselves no men." Thus, there could be no veritable threat to "the commonness, not to say absolute universality, of Religion" (Howe 1702:28-9). Indeed, to deny the humanity of people without religion required less effort than to rethink one's entire anthropology (Synge 1703:14-5). At the end of the century, it was still popular to define "man by animal religiosum," rather "than animal rationale" (Charnock 1797:10). By implication, those who lacked religion also lacked humanity.

Another strategy was to suggest that travellers had made flawed observations. In 1691, the scientist Robert Boyle had instituted a lectureship in his last will and testament for the defence of the Christian faith against atheists. Several of the sermons preached in his name reproduced this argument in order to prove that religion could not arise from the invention of any "cunning and designing Person" (Bentley 1739:384). John Hancock agreed that since navigation has improved and many unknown peoples had been discovered, some had pretended to find exceptions from the general rule that no nation is so barbarous as not 
to have belief in God. But, he added, there are good reasons why these should not be taken seriously. It is obvious that "those that by accident light upon such barbarous Countries, can take but a transient View of any of the Customs of such Countries, much less of their Religion, or their Notions of a God." Had they stayed longer, they might have come to other conclusions. In some cases, later travellers had indeed given another account of these peoples. Furthermore, a few cases from the uncivilized parts of the world could hardly count as exceptions to the general consent of humanity. Finally, it is well possible that "those Nations that are said to be Exceptions to the universal Consent of Mankind in this Matter, may believe a God, and yet have no Rites of Public Worship, and so be thought not to own a God" (Hancock 1739:205-6; see Leng 1739). So these alleged exceptions were without significance.

A third strategy was to ignore the reports. As travellers to all corners of the world had confirmed, one pseudonymous author noted, "go where you will, you shall never outtravel Religion" (Phylopsyches 1702:113). These authors had no qualms to insist, against the judgement of the travellers in question, that the latter had indeed found religion everywhere. In the Americas, explorers had denied the existence of religion among the Carib of Brazil, the Indians of Florida, the Topinamba Indians of the Maranón basin, all native Brazilians... In spite of this growing list, commentators continued to state from the beginning to the end of this century that religious notions of a deity had been found among all peoples in the vast continent of America (Woodward 1707:65-6; Charnock 1797:10).

Once the explorers' observations had been denied, reiterating "the universal Consent of Mankind" was the task that remained (Adams 1718:28). The most popular works on religion did so avidly. In his Private Thoughts Upon Religion, which saw more than twenty editions between 1709 and 1776, William Beveridge (1709:14) noted that "as there is no Nation or People in the World but acknowledge some Deity; so there is none but Worship that Deity which they acknowledge; yea, tho' it be but a Stick or a Stone, yet if they fancy any thing of Divinity in it, they presently perform Worship and Homage to it." Most authors continued to reproduce the argument from universal consent as though dissenting reports did not exist. Citing as evidence the same phrases from Cicero, they referred to "the histories of all ages" and "travellers into all countries" as empirical confirmation. ${ }^{4}$

\footnotetext{
${ }^{4}$ William Derham's Astro-Theology (1715), a bestseller with 14 editions between 1715 and 1775, quoted Cicero explicitly as proof for the omnipresence of religion. A plethora of eighteenth-century authors and preachers reproduced his words to state what once again appeared as a self-evident fact: Anonymous 1723:45; Anonymous 1775:258; Bull 1713:1081; Applegarth 1776:74-5; Balfour 1763:167-8; Bennet 1732:653-4; Boyer 1726:11; Burckhard 1797:70; Carroll 1709:101; Carter 1720:56; Conant 1736:120; Dutens 1769:394-5.
} 
What we see happen in the course of the eighteenth century is the transformation of theological postulates into anthropological facts. Perhaps no texts illustrate this so strikingly as the early encyclopaedias. In a multi-volume Universal Library, Henry Curzon started the entry "Religion" with the obvious: "From the beginning of Time, there was no Nation so rude or barbarous, but did set apart some solemn or publick Places for the worship of Deities..." (Curzon 1722:46-7). In the entry "Religion, or Theology" of the third volume of the Encyclopaedia Britannica of 1771, the theology is still obviously present: "From the first knowledge that we have of the world, that is to say, for about five thousand years past, men have blindly searched after the idea of the true God; and by the weakness of their discernment, they have fallen into a thousand errors" (Smellie 1771, vol. 3:533). In contrast, the first American encyclopaedia from the turn of the century sounded much like today's scholarly tracts about religion. "The slightest knowledge of history is sufficient to inform us," its entry on Religion stated, "that religion has ever had a powerful influence in moulding the sentiments and manners of men...Religion seems to be congenial to the heart of man; for wherever human society subsists, there we are certain of finding religious opinions and sentiments." Its reflections could come from the pages of contemporary religious studies:

The foundation of all religion rests on the belief of the existence of one or more superior beings, who govern the world, and upon whom the happiness or misery of mankind ultimately depends...No nation or tribe has ever been found, in which there is not reason to believe that some notions were entertained of superior and invisible powers, upon which depends the happiness or misery of mankind.

Once the entry began to speculate about the origins of religion, however, its theological inheritance re-surfaced. Either "the image of Deity must be stamped on the mind of every human being, the savage as well as the sage," or the founders of societies had discovered the existence of superior beings and communicated it to their followers, or this universal belief had been derived from a primeval revelation (Anonymous 1798, vol. 16:60).

This entry illustrates a crucial shift that would shape the study of religion for centuries to come. The apparent discovery of peoples without religion had constituted empirical anomalies with respect to a particular theory. That is, the observation that some tribes did not know of any deity, and therefore had no religion, was possible and significant only because of a specific theoretical framework operating in the background, namely generic Christian theology. In response to such anomalies, the most evident step is to immunize the theory against the empirical anomalies it confronts by making ad hoc changes. 
The encyclopaedia entry embodies one such immunizing modification: redefining one of the theory's theoretical terms. Instead of defining "religion" as "belief in the Deity," "awareness of the Supreme Being," or something similar, it now spoke of "religion" as the entertaining of notions of superior and invisible powers, upon which depends the happiness of humankind. It replaced an obviously theological concept with more neutral-sounding terms of description, and hence also neutralized the empirical anomalies: after all, all human nations had some notions of superior and invisible powers.

That this constituted no fundamental change to the theoretical framework is shown by the ease with which the entry moved back and forth between the two sets of concepts: it could easily shift from the "notions of superior and invisible powers shared by all nations" to explicitly theological concepts like "the image of the Deity stamped on the human mind" and "primeval revelation." Moving from one set of concepts to the other averted the need to engage in any major rethinking of the anthropology embedded in the western common sense by this time. It could keep the basic conceptual framework stable by substituting some of its terms. The same cognitive move, we will now see, determined the conceptual framework of the twentieth-century study of religion.

\section{The Establishment of an Anthropological Fact}

The last quarter of the nineteenth century became the stage for the closing debate about the universality of religion. ${ }^{5}$ Its instigator was the natural historian Sir John Lubbock, who published his Prehistoric Times in 1865. In a crucial passage, Lubbock (1971:574) raised the question "whether there is any race of men so degraded as to be entirely without a religion." The answer, he suggested, depends on the meaning one gives to the term "religion." If one defines it as a mere fear of the unknown or vague belief in witchcraft, then the answer is negative. But if one held a higher conception of religion, then the answer is a resounding "yes," since the most savage races never had this kind of religion. Lubbock then gave a list of observations on the absence of religion among all kinds of tribes in Africa, the Americas, and Asia. Many travellers and missionaries, he noted, had fully expected to find religion everywhere but were almost against their will convinced that the reverse was the case (1971:574-9).

"Are there, or have there been, tribes of men so low in culture as to have no religious conceptions whatever?" Thus Edward Tylor announced his contribution to the debate in 1871. He listed a series of similar observations, but then dismissed these with a

\footnotetext{
${ }^{5}$ See Day (2008) for an interesting analysis of Charles Darwin's contribution to this debate.
} 
philosophical point: "Such cases show how deceptive are judgments to which breadth and generality are given by the use of wide words in narrow senses" (Tylor 1970:3). Hasty denials of religion in certain tribes carried no great weight, he continued, since these scholars had judged without facts. Tylor gave the example of Sir Samuel Baker who had denied all forms of religion to a people of the White Nile. Baker, however, did not realise that the "first requisite in a systematic study of the religions of the lower races, is to lay down a rudimentary definition of religion." Such a definition, Tylor pointed out, need not include the notion of a Supreme Being. Rather, he defined religion as "the belief in spiritual beings," which did appear among all races, as "the immense mass of accessible evidence" showed. Even if one found a race without this belief in spiritual beings, Tylor (1970:7-9) added, this merely indicated that these human beings were "representatives of the condition of Man before he arrived at the religious state of culture."

Generally, two objections exhausted the opposition to the claim that there were cultures without religion. On the one hand, an earlier strategy was revived: accusing the travel reports of inaccurate observation. Travellers had not spent enough time among the natives or did not know their languages sufficiently well. Besides, later visitors had seen religion among the same peoples (Flint 1880:260-89). On the other hand, one accused the travellers or theorists in question of using unacceptably narrow definitions of "religion." This was the approach of Tylor and also of the two works that would close the nineteenthcentury debate in favour of the universality of religion: L'espèce humaine (1879) by the French anthropologist Armand de Quatrefages and Outlines of the History of Religion (1905) by the Dutch religion scholar Cornelis Petrus Tiele.

Because he was compelled to review all races in his teaching, de Quatrefages had looked for atheism in the lowest as well as the highest, and found it nowhere, except in certain individuals and schools of thought in modern Europe. He added his own definition of "religion" focussing on two characteristics: namely, "a belief in beings superior to man and capable of exercising a good or evil influence upon his destiny; and the conviction that the existence of man is not limited to the present life, but that there remains for him a future beyond the grave." Every human being and people possessing these characteristics is religious, he stipulated, and "observation shows more and more clearly every day the universality of this character" (Quatrefages 1890:484). Tiele (1905:6) reasoned in much the same way, when he said that inaccurate observation and the confusion of ideas had prevented some minds from realising that all nations had a "belief in any higher beings." 
In spite of its continuing popularity, we need to highlight the peculiarity of this claim that the presence or absence of religion depends on how one defines the word "religion." Consider the following: the debate on the consensus gentium had been so persistent through the centuries because fundamental problems of Christian doctrine were at stake. The basic terms of the debate - "Supreme Being," "religion," "worship," "divine"... - were theoretical terms within this framework of Christian doctrine. Consequently, the meaning and reference of terms like "religion" and "worship" were constrained by the framework in which they were embedded: fundamentally, "religion" referred to humanity's inclination and desire to worship the biblical God, and to the different forms this could take, from true Christianity to the worship of "sticks and stones." Therefore, whenever the empirical question was raised as to whether or not some people possessed religion, scholars could settle this only by taking recourse to this conceptual framework.

This has an important implication. From the philosophy of science, we know that we have no access to facts but only to descriptions of facts, and that such descriptions are always structured by some conceptual framework. When early modern Europeans had concluded that some non-western people had religion and began to describe its religion, these descriptions were structured by the theological background framework. Yet, the resulting descriptions were soon mistaken for obvious facts about the world. This is indicated by the following striking fact: when there was agreement that some people - say, "the Hindus" or "the Mayas" - had religion, this people could no longer be involved in debates about the consensus on the universality of religion (e.g. Craufurd 1790:4-5). One could challenge the consensus only by pointing to some newly discovered "tribes" about which such agreement had not yet been reached in Europe.

Consequently, if these nineteenth-century thinkers had intended to critically examine the consensus about the cultural universality of religion, they would have to question all the dominant European descriptions of the "religions" of Asia, Africa and the Americas and fundamentally re-examine the relevant cultures. They could not just assume that these cultures had religion, since that conclusion had been reached by drawing on the theological framework and its conception of human nature, including the belief in the consensus gentium. They could not just accept the descriptions of "Hinduism," "Buddhism," "Animism"... as facts, since these descriptions of the facts had been structured by the very same framework and its theoretical terms. The only way to move away from the earlier theological consensus was to once again involve all these cultures, and not just some exotic tribes, into the debate about the universality of religion. Instead of doing so, however, they 
re-defined one term within the larger framework and kept both this framework and its concomitant descriptions of the various "religions" of humanity stable. Eventually, this allowed them to conclude that there were no peoples without religion. Cognitively speaking, this move was economic, but it also came with a heavy price: that of accepting theological claims as theory-neutral anthropological facts.

Let us illustrate this historically. When Lafitau or More addressed the question as to whether all human groups had religion, the nature of this object of religion was clear to them: religion was the awareness of God's existence given by Him to humanity (and all too often corrupted later). Because of the absolute theological certainty that religion existed everywhere, European travellers saw its presence in all kinds of practices, stories, and texts they encountered in other parts of the world. A variety of terms from Asian and African traditions were translated as "God" or "Supreme Being" or "Deity," since it was indubitable that these people had some awareness of the biblical God. If no plausible equivalent was found, scholars stipulated that among the people in question the instinctive awareness of God had degenerated into spirit worship or something else. In short, a specific theoretical framework provided one with conceptual criteria to confirm the presence or absence of religion among certain alien cultures and gave structure to the resulting descriptions of these cultures.

What would happen, if this theological framework were to shift into the background and its doctrinal issues were transformed into anthropological questions? Suddenly, one no longer possessed the theological account about the original religion to establish its universality. At the same time, this framework had not been replaced with any new theory that identified the structure and properties of the object of religion. In other words, one lacked criteria to test its presence or absence in any given society. All one had left, were the term "religion," certain commonsense notions about the object it referred to, and a whole body of descriptions of the "religions" of non-western cultures, all inherited from more than fifteen centuries of Christian theorizing.

These, I would like to suggest, were the conditions under which Tylor, Tiele, and their contemporaries approached the issue at hand. They no longer said that all human beings had a sense of the biblical God, for this was an explicitly theological claim. But they were even less open to challenging the belief in the cultural universality of religion, since this piece of theology had been ingrained in the western common sense. As in previous centuries, the "fact" of universality was restored through repetition. Instead of the great 
orator, the historian (Tiele) and the anthropologist (de Quatrefages) became the experts who had established this once and for all. ${ }^{6}$

Early in the twentieth century, a phrase appeared that would replace Cicero's claim as the new truism: "Man is incurably religious." The phrase, taken from Auguste Sabatier (1903:6), led authors from all disciplines to grand claims about humanity. Comparative religion discovered its truth and suggested that religion was a psychological necessity: "Man is religious before he is fully aware of the fact" (Jordan 1905:337). The educationalist could not agree more: "Man is alone the religious animal, and he cannot escape the demand of religion until he escapes from his deepest self" (King 1908:103). Historians, psychologists and others reproduced the same words: "Man is a worshiping animal; he is 'incurably religious'"' (Barton 1919:3). $^{7}$

\section{Curing the Incurable?}

From the foregoing, we can conclude that a genuine scientific debate about the cultural universality of religion never occurred in western scholarship, because the terms of description and debate had been set by a theological background framework. A constitutive element of this framework was the presupposition that all nations had some form of religion. Over decades and centuries, the dominant descriptions of the presumed "religions" of Asia, Africa and the Americas were purged of their explicitly theological content. More empirical anomalies were pointed out: scholars showed that belief and doctrine were not central in some religions; others pointed out that many religions had no creeds, sacred scriptures, ecclesiastical structures, or organized modes of worship. In response to such anomalies, new ad hoc modifications also followed: the term "religion" and its cognates became increasingly more "flexible" as the term was defined in more encompassing ways. It was added that there were different kinds of religion and that we should not map all religions on the model of Christianity. Nonetheless, the basic conceptual structure of the descriptions of non-western religions remained in place. This can be inferred from the fact that western scholars and laymen continued to speak and write of "Hinduism," "Buddhism," "Bantu religion," "Hopi religion" ... as though it was self-evident that such entities existed. For those non-western peoples concerning whom agreement had emerged at some point in the history of western scholarship that they did have religion, this agreement was not to be disputed again.

\footnotetext{
${ }^{6}$ Braden 1879:299; Bros 1907:333; Crofton 1885:5; Duke of Argyll 1884:281; Hill 1893:300-1; Illingworth 1898:55; Le Roy 1922:286-7; MacFarlane 1904:14.

${ }^{7}$ See Eddy 1922:57; Pratt 1921:61; Tyler 1921:x-xi; Van Ness Myers 1913:251.
} 
It is here that a new challenge has emerged, which is of a fundamentally different kind than the past disputes about the universality of religion. We shall draw on the work of Balagangadhara (1994) to explain this challenge because he formulates it in unambiguous terms. First of all, Balagangadhara questions the factual status of the descriptions of the "religions" of Asia. The entities of "Hinduism," "Buddhism," “Jainism," "Sikhism"... crystallized within the framework of a secularized Christian theology. Occurring within this framework, the everyday observations of European travellers and the systematic reflections of orientalist scholars concurred in gradually creating such conceptual entities or coherent patterns of description. In the process, texts reflecting on the nature of the self and human experience were transformed into "doctrines about God." Rituals and practices were systematically re-described as the "worship" of gods, ancestors or other spiritual beings. Traditional stories and legal treatises were taken as representations of the "religious beliefs" of a people. The resulting descriptive entities were the "religions" of India. Thus, the "Hindu, Buddhist, Jain and Sikh religions" came into being not as theory-neutral facts but as descriptions informed at every level by a cultural background framework of generic Christian theology.

Second, Balagangadhara (2010:136-9) argues that the conceptual patterns of entities like "Hinduism" or "Taoism" do not correspond to patterns present in the relevant peoples' experiences of their own traditions and practices. These religions do not exist in the cultures where they are supposed to. They are fictitious entities. When religious entities like "Hinduism" are postulated, the resulting descriptions may make sense to Western scholars and laymen, but they are inaccessible to the people described. Balagangadhara (1994:318423) goes further. He develops an alternative theory of religion, which explains why Western culture was compelled to see religion in all other cultures, and then traces the empirical consequences of this theory to demonstrate that there can be no "indigenous" religion in Indian culture. Consequently, religion is emphatically not a cultural universal.

There is no need to go into these arguments here in order to appreciate the challenge that Balagangadhara puts before the contemporary study of religion: Which are the theoretical or empirical criteria that allow us to test and demonstrate the presence of religion in some culture, without already presupposing that this culture has religion? To define "religion" in some encompassing way and suggest that it exists wherever there is belief in "spiritual beings" or "supernatural agency" is to evade this issue. The problem is not that of finding terms, definitions and descriptions sufficiently vague to encompass all entities that we believe to be religions. Instead, we are challenged to re-examine the extant 
descriptions of the presumed "religions" of Asia, Africa and the Americas, in order to demonstrate that these religious entities exist and that these descriptions are not dependent on theological foundations. ${ }^{8}$

This new challenge is extremely relevant to the recent crop of evolutionarybiological explanations of religion. These explanations claim to be scientific as they locate the origin and causes of religion in the biological evolution (and the resulting cognitive structures and cooperation mechanisms) of the human species. Now, if only some limited number of human communities had religion, it would scarcely make sense to search for its origin in the biological evolution of Homo sapiens. In that case, the question of the origin of religion would become a historical issue, much like the origin and spread of democracy in human societies.

The first challenge, then, is that evolutionary-biological explanations of religion should not presuppose the cultural universality of religion instead of demonstrating it. Yet, they seem to be doing precisely that. Daniel Dennett (1997:39) notes that human groups "have gone without agriculture, without clothing, without laws, without money, without the wheel or without writing, but not apparently, without religion." Scott Atran (2002:4) claims the following: "All known human societies, past and present, bear the very substantial costs of religion's material, emotional, and cognitive commitments to factually impossible worlds." In the words of yet another evolutionary theorist: "As far back as we can trace human history, there has always been religion" (Rosano 2010:1). Such citations can be multiplied (Broom 2003:xi, 164, Burkert 1996:1, Hinde 1999:2). They function as grounds for arguing for the plausibility or even necessity of evolutionary-biological explanations of religion. The same certainty also shapes the questions raised by Pascal Boyer in his Religion Explained (2001:4): "What is the origin of religious ideas? Why is it that we can find them wherever we go and, it would seem, as far back in the past as we can see?" Other authors also "want to know why religion has throughout history been universal in human societies" and add that "we have learned from anthropology that religion is (in some form or another) universal across human societies" (Kirkpatrick 2005:11, 17).

In other words, these evolutionary-biological explanations take as their explanandum the belief that religion is found in all human societies. The only evidence they provide consists of pointers to earlier anthropologists and historians. However, this cannot suffice as evidence: First, the fact that many people have perceived something to be the

\footnotetext{
${ }^{8}$ This should not be confused with the "constructivist" claim that religions in general do not exist, but that the category of religion is merely a classificatory conceptual tool of the scholar (see De Roover and Claerhout 2010 for an explanation).
} 
case does not count as evidence for its truth. Otherwise our recurrent perception that the sun revolves around the earth would have to count as evidence for the truth of geocentric models of the universe. Second, in so far as there is (or was) a scholarly consensus that religion is universal across human societies, this rests on the conclusion reached in the early twentieth-century debate on peoples without religion. But that conclusion, we saw, reproduced the earlier theological consensus with suitable ad hoc modifications. Thus, the first challenge posed by Balagangadhara to these explanations of religion is that they have to demonstrate the truth of their explanandum. If they cannot, then these explanations will turn out to be exercises in the fallacy of petitio principii (presupposing what one has to prove).

The other major challenge lies in the fact that the evolutionary-biological explanations of religion have accepted the dominant descriptions of the presumed "religions" of humanity as theory-neutral facts in need of explanation. In doing so, they ignore that many of these descriptions rely on (and hence reproduce) a conceptual framework and theoretical terms of Christian-theological stock. Let us briefly illustrate this. In his work on the evolutionary landscape of religion, Scott Atran (2002:52) states the following "fact" as self-evident:

In all religions, and thus in all societies, people believe that agents unseen have intentionally generated the world we see. God created the world for us on purpose and knows what is true. Given that people believe in truthful and purposive supernatural agents, they are able to sanctify the moral order and hold the group to commitment (italics added).

This claim is problematic. It is untrue that in all societies, people believe that invisible agents have intentionally generated the visible world. In some cultures, the various accounts of the origin of the world conceive of the world as the unintentional result of some sequence of events or acts. In the Indian traditions, for instance, there are several such accounts; Jains even deny any possibility of a creation of the universe or creator god (Balagangadhara 1994:398-412). Yet, Atran (2002:53) insists that all societies explain the world in terms of "the supernatural establishment of order from the midst of primordial chaos. The order that is established derives from the thoughts and intentions of divine beings." He gives the following example: "In Hindu religious iconography, Vishnu is often represented dreaming the world, as he hovers over the Milky Way while lying on the serpent Ananta ("Unending")." To this account, however, the Hindu traditions add dozens of other accounts about the coming into being of the world. Many of these do not explain it in terms of the 
thoughts and intentions of divine beings. In fact, even Vishnu's creation of the world happens through "Iil|a" or "play" and not through an act of creation that expresses his intentions.

How has Atran come to such generic but false statements about all societies? His facts derive from the way in which Christian-theological reflection has systematically conceptualized the "religions" and "gods" of non-western cultures over the centuries. The idea that the deities of all such religions were taken by their followers to be invisible agents who intentionally created and governed the world was central to the concept of "false religion." In true religion, it was said, believers knew that the true God was the sole creator and sovereign of the universe, whose divine will governed all that was. In contrast, the followers of false religion did not realize this and mistakenly attributed the capacity to rule the world to certain creatures and worshipped these as divine beings. According to this theological explanation, these gods were false (among other reasons) because it was wrongly believed that their intentions governed the world and caused its events. This was essential to the theological notion of "false gods." This notion gave structure to early modern European conceptions of non-western "religions," which systematically described their "gods" or "deities" as intentional agents whose purposes are supposedly expressed in natural events (David Hume's Natural History of Religion (1757) is a well-known example).

While Atran renounces the terminology of "false gods," he reproduces this notion by arguing that, in all religions and societies, people believe that agents unseen have intentionally generated the visible world. He is not alone here. Other authors of biological explanations of religion similarly give great importance to the "fact" that people in all religions believe that natural events are caused by the intentional agency of supernatural beings (Barrett 2000:31, Boyer 2001:144-8, Dennett 2006:114-7). They explain this as the byproduct of an adaptive capacity of human perception to detect intentional or human-like agency in the environment. Without going into the cognitive value of this explanation, we should note here that such factual claims about humanity's "religions" and their "supernatural beings" need to be re-examined before they could even serve as facts in need of explanation. This is the case because these "facts" stem from descriptions of these "religions" that are structured by a theological conceptual apparatus.

Most importantly, this is true for the belief that the religions of Asia, Africa and the Americas exist in the first place. The most basic descriptive layer of our descriptions of these "religions" had emerged from the consensus gentium. All later descriptions built on the presumption that these religions existed and thus also continued the Christian-theological 
consensus. Consequently, the evolutionary theorists of religion fail to realize to what extent the descriptions of their data have been shaped by a particular theoretical framework, namely, that of generic Christian theology.

\section{Conclusion}

Given that the debate on the cultural universality of religion has been reopened, the contemporary study of religion is in a unique position to settle this issue on reasonable theoretical grounds. If Balagangadhara is right, then religion is not a cultural universal and many of the "religions" that have been attributed to humanity will prove to be non-existent. If the evolutionary-biological theorists of religion are right, however, then religion must be a cultural universal and some form of religion should have existed among all human peoples.

This essay has traced the historical development of the debate on the universality of religion in order to explain the issues at stake. When the scientific study of other cultures took off in the early twentieth century, it did not begin in a vacuum. Western scholars presupposed the claim that Christian thinkers had "established" and "re-established" much before them: religion is a cultural universal. That is to say, they did not empirically find out whether there were religions in the many communities and societies of Asia, Africa or the Americas. They reproduced the belief in the existence of multiple religions, accepted the basic descriptions of these "religions" that had circulated for centuries, and assumed too that they were describing various aspects of such entities when they did their fieldwork and historiography. They assumed all of this without any genuine empirical or theoretical support.

When the evolutionary theorists of the twenty-first century appeal to the work of earlier scholars to assert the universality of religion, they are not giving any other evidence except what people in the West have believed to be the case for centuries. It is time for us to realize that something strange has happened. With appropriate modifications, the Christian theologian's claim of consensus gentium has ensconced itself in western common sense in the form of the widespread intuition that religion is universal across all human societies. Many contemporary theorists of religion take this intuition as a given. "There is an innate sense of divinity in men" says one; "yes, but in the form of memes or genes," says the other. If we really intend our study of religion to be scientific, then we shall have to critically re-examine the facts inherited from fifteen centuries of Christian-theological reflection about humanity. 


\section{References}

Adams, Samuel. 1718. A Plain and Full Instruction in the Principles and Doctrines of the Christian Religion. Oxford.

Allestree, Richard. 1673. The Ladies Calling in Two Parts. Oxford.

Anonymous. 1723. A Dissertation on the Law of Nature, the Law of Nations, and the Civil Law in General. London.

Anonymous. 1775. The Beauties of History; Or, Pictures of Virtue and Vice, Drawn From Real Life; Designed as an Introduction to the Art of Thinking and Reflection. Dublin.

Anonymous. 1798. Encyclopaedia; or, A Dictionary of Arts, Sciences, and Miscellaneous Literature, vol. 16. Philadelphia.

Applegarth, Robert. 1776. A Theological Survey of the Human Understanding: Intended as an Antidote Against Modern Deism. Salisbury.

Asad, Talal. 1993. Genealogies of Religion: Discipline and Reasons of Power in Christianity and Islam. Baltimore: The Johns Hopkins University Press.

Atran, Scott. 2002. In Gods We Trust: The Evolutionary Landscape of Religion. New York: Oxford University Press.

Balagangadhara, S.N. 1994. "The Heathen in His Blindness...": Asia, the West and the Dynamic of Religion. Leiden: Brill.

Balagangadhara, S.N. 2010. "Orientalism, Postcolonialism and the 'Construction' of Religion." In Rethinking Religion in India: The Colonial Construction of Hinduism, ed. Esther Bloch, Marianne Keppens and Rajaram Hegde. London and New York: Routledge, 135-163.

Balfour, James. 1763. A Delineation of the Nature and Obligation of Morality. Edinburgh.

Barton, George A. 1919. The Religions of the World. Chicago: The University of Chicago Press.

Baxter, Richard. 1672. More Reasons for the Christian Religion and No Reason Against It. London.

Bennet, Benjamin. 1732. The Christian Oratory. London.

Bentley, R. 1739. "Sermon III: The Notion of God, neither from Fear nor Policy." In A Defence of Natural and Revealed Religion: Being a Collection of the Sermons Preached at the Lecture Founded by the Honourable Robert Boyle, Esq, vol. 1. London.

Beveridge, William. 1709. Private Thoughts Upon Religion: Digested Into Twelve Articles. London.

Boyer, Pascal. 2001. Religion Explained: The Evolutionary Origins of Religious Thought. New York: Basic Books. 
Boyer, Pierre. 1726. A Parallel of the Doctrine of the Pagans, with the Doctrine of the Jesuits. London.

Braden, Clark. 1879. The Problem of Problems, and its Various Solutions; or, Atheism, Darwinism, and Theism. Cincinnati, $\mathrm{OH}$ : Central Book Concern.

Brerewood, Edward. 1614. Enquiries Touching the Diuersity of Languages, and Religions Through the Cheife Parts of the World. London.

Broom, Donald M. 2003. The Evolution of Morality and Religion. Cambridge: Cambridge University Press.

Bros, A. 1907. La Religion des peuples non civilisés. Paris: P. Lethielleux.

Bull, George. 1713. Some Important Points of Primitive Christianity Maintained and Defended, Vol. 3. London.

Burckhard, Johann Gottlieb. 1797. A System of Divinity, For the Use of Schools, and For Instructing Youth in the Essential Principles and Duties of Religion. London.

Burkert, Walter. 1996. Creation of the Sacred: Tracks of Biology in Early Religions. Cambridge, MA: Harvard University Press.

Calcott, Wellins. 1756. Thoughts Moral and Divine. London.

Caldecott, Alfred. 1901. The Philosophy of Religion in England and America. New York: MacMillan.

Care, Henry. 1683. The Darkness of Atheisme Expelled by the Light of Nature. London.

Carroll, William. 1709. Spinoza Reviv'd. London.

Carter, John. 1720. Sermons upon Several Texts of Scripture. London.

Charnock, Stephen. 1797. Discourses Upon the Existence and Attributes of God. London.

Cicero, Marcus Tullius. 1971. Tusculan Disputations, trans. by J.E. King. Loeb Classical Library. Cambridge, MA: Harvard University Press.

Columbus, Christopher. 1968. The Journal of Christopher Columbus, trans. by Cecil Jane. London: Anthony Blond.

Conant, John. 1736. Sermons on Several Subjects. Oxford.

Craufurd, Quintin. 1790. Sketches Chiefly Relating to the History, Religion, Learning, and Manners of the Hindoos. London.

Crofton, Henry W. 1885. Evolution and Moral Sense: A Lecture. London: Rivingtons.

Cudworth, Ralph. 1678. The True Intellectual System of the Universe. London.

Curzon, Henry. 1722. The Universal Library: Or, Compleat Summary of Science, vol. 1. London.

Dawkins, Richard. 2006. The God Delusion. Boston: Houghton Mifflin. 
Day, Matthew. 2008. "Godless Savages and Superstitious Dogs: Charles Darwin, Imperial Ethnography, and the Problem of Human Uniqueness." Journal of the History of Ideas 69(1):49-70.

De Quatrefages, Armand. 1890. The Human Species. New York: D. Appleton and Company. De Roover, Jakob and Sarah Claerhout. 2010. "The Colonial Construction of What?" In Rethinking Religion in India: The Colonial Construction of Hinduism, ed. Esther Bloch, Marianne Keppens and Rajaram Hegde. London and New York: Routledge, 164-184.

De Waal Mallefijt, Annemarie. 1968. Religion and Culture: An Introduction to Anthropology of Religion. New York: The Macmillan Company.

Dennett, Daniel C. 1997. “Appraising Grace: What Evolutionary Good is God?" The Sciences, January/February:39-44.

- - 2006. Breaking the Spell: Religion as a Natural Phenomenon. New York: Allen Lane.

Derham, William. 1715. Astro-Theology or, a Demonstration of the Being and Attributes of God, from a Survey of the Heavens. London.

Dow, Alexander. 1768. The History of Hindostan. London.

Dowey, Edward A. 1952. The Knowledge of God in Calvin's Theology. New York: Columbia University Press.

Dubuisson, Daniel. 2003. The Western Construction of Religion: Myths, Knowledge, and Ideology, trans. by William Sayers. Baltimore: The Johns Hopkins University Press.

Duke of Argyll. 1884. The Works of the Duke of Argyll. New York: John B. Alden.

Dutens, Louis. 1769. An Inquiry into the Origin of the Discoveries Attributed to the Moderns. London.

Eddy, Sherwood. 1922. Facing the Crisis: A Study in Present Day Social and Religious Problems. New York: George H. Doran Company.

Eusebius. "Church History from A.D. 1-324." In Nicene and Post-Nicene Fathers, vol. 1, ed. Phillip Schaff \& Henry Wace. Peabody: Hendrickson, 81-403.

Fitzgerald, Timothy. 2007. Discourse on Civility and Barbarity: A Critical History of Religion and Related Categories. Oxford: Oxford University Press.

Flint, Robert. 1880. Anti-Theistic Theories. Edinburgh \& London: William Blackwood and Sons.

Goodman, Godfrey. 1622. The Creatures Praysing God: Or, the Religion of Dumbe Creatures. London.

Hale, Matthew. 1684. The Judgment of the Late Lord Chief Justice Sir Matthew Hale, of the Nature of True Religion. London. 
Hancock, John. 1739. "Arguments to prove the being of God." In A Defence of Natural and Revealed Religion: Being a Collection of the Sermons Preached at the Lecture Founded by the Honourable Robert Boyle, Esq, vol. 2. London, 201-245.

Harrison, Peter. 1990. 'Religion' and the Religions in the English Enlightenment. Cambridge: Cambridge University Press.

Herbert of Cherbury, 1937. De Veritate, trans. by Meyer H. Carré. Bristol: Arrowsmith for the University of Bristol.

Herskovits, Melville J. 1956. Man and His Works: The Science of Cultural Anthropology. New York: Alfred A. Knopf.

Hill, David J. 1893. Genetic Philosophy. New York: Macmillan.

Hinde, Robert A., 1999. Why Gods Persist: A Scientific Approach to Religion. London \& New York: Routledge.

Hoult, Thomas F. 1958. The Sociology of Religion. New York: Dryden Press.

Howe, John. 1702. The Living Temple: Or, a Designed Improvement of that Notion that a Good Man is the Temple of God. London.

Idel, Moshe. 2002. "Prisca Theologia in Marsilio Ficino and in Some Jewish Treatments." In Marsilio Ficino: His Theology, His Philosophy, His Legacy, ed. Michael J. B. Allen and Valery Rees, Leiden: Brill, 137-158.

Illingworth, J. R. 1898. Personality Human and Divine: Being the Bampton lectures for the Year 1894. London: Macmillan.

Jevons, Frank B. 1896. An Introduction to the History of Religion. London: Methuen \& Co.

Joly, Nicholas. 1889. Man before Metals. New York: D. Appleton and Company.

Jordan, Louis H. 1905. Comparative Religion: Its Genesis and Growth. Edinburgh: T. \& T. Clark.

Justin Martyr. "Hortatory address to the Greeks." In The Ante-Nicene Fathers: The Writings of the Fathers Down to A.D. 325, vol. 1, ed. Rev. Alexander Roberts \& Sir James Donaldson. Grand Rapids: Wm. B. Eerdmans, 1989, 273-289.

King, Henry C. 1908. Personal and Ideal Elements in Education. New York: The Macmillan Company.

Kirkpatrick, Lee A. 2005. Attachment, Evolution, and the Psychology of Religion. New York \& London: Guilford.

Kors, Alan C. 1990. Atheism in France 1650-1729, vol. 1: The Orthodox Sources of Disbelief. Princeton: Princeton University Press. 
Lach, Donald. 1965. Asia in the Making of Europe, vol. 1: The Century of Discovery. Chicago: The University of Chicago Press.

Lactantius, "The Divine Institutes," trans. by Rev. William Fletcher. In The Ante-Nicene Fathers, ed. Rev. Alexander Roberts \& Sir James Donaldson, vol. 7, 9-223.

Lafitau, Joseph F. 1974. Customs of the American Indians Compared with the Customs of Primitive Times, vol. 1, trans. by William N. Fenton \& Elizabeth L. Moore. Toronto: The Champlain Society.

Le Roy, Alexander. 1922. The Religion of the Primitives. New York: The Macmillan Company.

Leng, John. 1739. "Natural Obligations to Believe the Principles of Religion and Divine Revelation: In Sixteen Sermons." In A Defence of Natural and Revealed Religion: Being a Collection of the Sermons Preached at the Lecture Founded by the Honourable Robert Boyle, Esq, vol. 3. London, 5-152.

Llobera, Josep R. 2003. An Invitation to Anthropology: The Structure, Evolution and Cultural Identity of Human Societies. New York and Oxford: Berghahn Books.

Locke, John. 1700. An Essay Concerning Humane Understanding in Four Books. Fourth edition. London.

Lubbock, John. 1971. Prehistoric Times. Freeport, NY: Books for Libraries Press.

MacFarlane, Samuel. 1904. "My Experiences as a Pioneer Missionary amongst the Cannibals of New Guinea." Journal of the Manchester Geographical Society 20:8-28.

More, Henry. 1653. An Antidote Against Atheisme. London.

Morris, Brian. 1987. Anthropological Studies of Religion: An Introductory Text. Cambridge: Cambridge University Press.

Nelson, Eric. 2010. The Hebrew Republic: Jewish Sources and the Transformation of European Political Thought. Cambridge, MA: Harvard University Press.

Nottingham, Elizabeth. 1954. Religion and Society. New York: Random House.

O'Briant, Walter H. 1985. "Is There an Argument “Consensus Gentium'?" International Journal for Philosophy of Religion 18(1-2):73-79.

Pagden, Anthony. 1987. The Fall of Natural Man: The American Indian and the Origins of Comparative Ethnology. Cambridge: Cambridge University Press.

Phylopsyches, Alethius. 1702. Psychelogia; or Serious Thoughts on Second Thoughts. London.

Pratt, James B. 1921. The Religious Consciousness: A Psychological Study. New York: The MacMillan Company.

Preus, J. Samuel. 1977. "Zwingli, Calvin and the Origin of Religion." Church History 46:186202. 
Rihbany, Abraham M. 1922. Wise Men from the East and from the West. Boston \& New York: Houghton Mifflin.

Rosano, Matt J. 2010. Supernatural Selection: How Religion Evolved. New York: Oxford University Press.

Ross, Alexander. 1655. Pansebeia, or, A View of All Religions in the World. London.

Sabatier, Auguste. 1903. Esquisse d'une Philosophie de la Religion d'après la Psychologie et I'Histoire. Paris: Librairie Fischbacher.

Saliba, John A. 1976. "Homo Religiosus" in Mircea Eliade: An Anthropological Evaluation. Leiden: E. J. Brill.

Smellie, William (ed.). 1771. Encyclopaedia Britannica; or, a Dictionary of Arts and Sciences, Compiled upon a New Plan, vol. 3. Edinburgh.

Staal, Frits. 1989. Rules without Meaning: Ritual, Mantras, and the Human Sciences. New York: Peter Lang Verlag.

Synge, Edward. 1703. A Gentleman's Religion: In Three Parts. London.

Tiele, Cornelis P. 1905. Outlines of the History of Religion: To the Spread of the Universal Religions. London: Kegan Paul, Trench, Trübner \& Co.

Tyler, John M. 1921. The New Stone Age in Northern Europe. New York: Charles Scribner's Sons.

Tylor, Edward. 1970. Religion in Primitive Culture. Gloucester, MA: Peter Smith.

Van Ness Myers, Philip. 1913. History as Past Ethics: An Introduction to the History of Morals. Boston: Ginn and Company.

Walker, D. P. 1972. The Ancient Theology: Studies in Christian Platonism from the Fifteenth to the Eighteenth Century. Ithaca: Cornell University Press.

Wallisch, Robert (ed.). 2002. Der Mundus Novus des Amerigo Vespucci: Text, Übersetzung und Kommentar. Wien: Österreichische Akademie der Wissenschaften.

Ware, Henry. 1842. An Inquiry into the Foundation, Evidences, and Truths of Religion, vol. 1. Cambridge: John Owen.

Wilkins, John. 1678. Of the Principles and Duties of Natural Religion Two Books. London.

Wilson, David S. 2002. Darwin's Cathedral: Evolution, Religion and the Nature of Society. Chicago \& London: The University of Chicago Press.

Winzeler, Robert L. 2008. Anthropology and Religion: What We Know, Think, and Question. Lanham, MD: AltaMira Press.

Woodward, Josiah. 1707. Fair Warnings to a Careless World, or, the Serious Practice of Religion Recommended by the Admonitions of Dying Men. London. 